\title{
Professor Rudolph Darko
}

Ghana Med J 2020; 54(2): 74 DOI: http://dx.doi.org/10.4314/gmj.v54i2.2

Professor Rudolph Darko was born on April 51948 and passed away on February 23 2020. He was a general surgeon with a particular interest in gastroenterology and gastrointestinal endoscopy.



At the time of his demise Professor Darko was an Associate Professor in the Department of Surgery, University of Ghana School of Medicine. He took up his teaching appointment in 1989 as a Lecturer and General Surgical specialist.

The Ghana Medical Journal remembers him especially as one of the longest serving members of its Editorial Committee. He was appointed to the Editorial Committee in 1996. His service to the journal was one of prompt review of manuscripts, participation as a resource person in scientific writing workshops and training of editorial committee members. His skills in scientific publishing served him well as Editor-in-Chief of the West African Journal of Medicine from 2012 to 2017.

In 1978, four years after his graduation as a medical doctor (in 1974) he was elected the National Treasurer of the Ghana Medical Association. This was a period in the history of Ghana where there was a lot of unrest and agitation by professional associations against the ruling military government. He continued to serve the Medical Association in various capacities and in 2003 he was awarded the highest honour of the Association, Fellow of the Ghana Medical Association.

Rudolph was key in the development of gastrointestinal endoscopy at the Korle Bu Teaching Hospital. It was during his term as Head of Department of Surgery that the current Endoscopy Unit of the hospital was re-located in 2007 from the Radiology Department to its current site. The period also saw the transition from fiberoptic endoscopy to video endoscopy. Professor Darko's contribution to the development of endoscopy in Ghana includes a strong relationship with colleagues from the Mayo Clinic in Rochester, USA and the University of Michigan, USA and the American Gastroenterology Association resulting in annual endoscopy training workshops for participants from Ghana, Nigeria, Sierra Leone and Ivory Coast.

Professor Darko will be remembered for his dedication to the establishment of the Advanced Trauma Operative Management (ATOM) Course Centre of which he was Director and Principal Instructor from its inception in February 2005 to July 2013. This Centre was central for skills training in Surgery in the West African sub-region. He was an instructor in Basic Surgical Skills, Endoscopy and anastomosis.

Professor Darko was admitted to the University of Ghana Medical School in October 1968 after his secondary education at the Presbyterian Secondary School at Odumase-Krobo, and Prempeh College, Kumasi in Ghana. At the University of Ghana, he was a keen sports person playing hockey, football and squash. He won his half Colours in 1970 and Full Colours for hockey at his hall of residence, The Commonwealth Hall.

Professor Darko started his residency training in General Surgery in Ghana in 1976 and continued to the United Kingdom in 1980 where he obtained the Fellowship of the Royal College of Surgeons at Edinburgh and London in 1982. He returned home to join the Ghana Medical School after a stint in Saudi Arabia as a Consultant General Surgeon.

In many respects he was a prominent individual in the development of postgraduate medical education in Ghana and the West African sub-region through the Ghana College of Physicians and Surgeons and the West African College of Surgeons. He was a Fellow of both Colleges and contributed to curriculum development, training and examinations. His contribution to Medicine was recognized with the award of Officer of the Order of Volta (Medicine) in 2008 by the President of the Republic of Ghana.

He is survived by his wife and three children.

\section{Professor David Ofori-Adjei FGA, FGCP \\ Editor-in-Chief, Ghana Medical Journal \\ E-mail: editor@ghanamedj.org}

